\title{
Two doctors die from Ebola and lives of others under threat in West Africa
}

\author{
Ingrid Torjesen
}

London

The risks to doctors while caring for patients in the outbreak of Ebola virus disease in west Africa became increasingly apparent this week when it was confirmed that a second doctor had died from the virus in a month and that at least two others had been infected.

The World Medical Association has warned that poor care practices were putting doctors' lives at risk in what has become the world's worst recorded outbreak of the disease. Reports have also emerged that doctors and officials trying to get to some villages in affected areas have been threatened by frightened local people doing all they can to keep outsiders and potential carriers of the virus out. Some communities are blaming aid agencies for spreading the virus and turning to traditional medicine rather than sending people with suspected cases to official Ebola clinics.

The present outbreak began in Guinea in February and spread to neighbouring Liberia and Sierra Leone. As at 23 July at least 1200 people were believed to have been infected, 672 of whom had died, show figures from the World Health Organization.

Last weekend Samuel Brisbane, a Liberian doctor, died from the disease. Brisbane, who had once been a medical adviser to the former Liberian president, Charles Taylor, worked at the country's largest hospital, the John F Kennedy Memorial Medical Center in the capital, Monrovia. His death came just days after it was announced that Sheik Umar Khan, a leading Ebola doctor in Sierra Leone, had been infected. In early July Samuel Mutoro, a senior doctor from Uganda, died after treating infected patients in Liberia.

A US doctor working with Ebola patients in Liberia has also tested positive for the disease. Kent Brantly, a family doctor from Fort Worth in Texas, recognised his own symptoms and confined himself to an isolation ward. Brantly came to Africa to work before the current Ebola outbreak started and is medical director at an Ebola case management centre run by Samaritan's Purse, a Christian charity. He is being treated at a hospital in Monrovia. Another US citizen working at the same Ebola case management centre with Brantly has also been infected.

The World Medical Association has warned about the inadequacy of the working conditions of many health professionals, especially junior doctors, caring for patients with Ebola virus disease. Nivio Moreira, who chairs the association's Junior Doctors Network, said, "We are appalled by reports that many junior doctors are not provided with protective equipment essential for dealing with such a deadly disease.
"We are also concerned about reports of unsupervised junior staff in the current Ebola outbreak, which needs high level of expertise to support the junior staff. These are major threats to all those working in these situations and go to the heart of safe working conditions."

Margaret Mungherea, the association's president, said,

"Governments have a responsibility to ensure that health workers are trained and provided with a safe workplace and protective gear."

The virus spreads through contact with an infected person's bodily fluids. Health professionals caring for infected patients are at particular risk and should use protective equipment such as individual gowns, gloves, masks, and goggles or face shields and should follow strict infection control procedures.

Meanwhile the New York Times has reported that groups of men wielding machetes, knives, and stones have been denying doctors and officials entry to their communities for fear that they will bring in the virus and have erected log barricades to keep outsiders out. ${ }^{1}$ The communities believe that aid workers from the Red Cross and Médecins Sans Frontières are spreading the virus so are sending potentially infected patients to be privately treated by traditional medicine in a nearby village without infection control precautions, rather than to an Ebola clinic.

The virus kills up to $90 \%$ of those infected, but the chance of survival is higher if patients are treated early.

A spokeswoman for Médecins Sans Frontières told The BMJ that the situation was improving because some of the villages were now allowing access. Around $70 \%$ of patients who had been treated in the organisation's isolation wards since March had survived, she added.

There is no specific treatment for Ebola virus disease. Patients are often dehydrated and require oral rehydration with solutions containing electrolytes or intravenous fluids. Severely ill patients require intensive supportive care.

Liberia has closed most border crossings and set up screening centres at the entry points that remain open. Public gatherings have been banned.

Last week an official died in Nigeria after flying from Monrovia to Lagos, raising fears that other passengers could have been infected and take the disease outside Africa. This was the first recorded case in Nigeria, and the country has shut and quarantined the hospital where the patient died while it is decontaminated. All entry points into Nigeria have also been 
put on red alert, and Nigeria's largest airline, Arik Air, has suspended all flights to Liberia and Sierra Leone.

Nossiter A. Fear of Ebola breeds a terror of physicians. New York Times 27 July 2014 www.nytimes.com/2014/07/28/world/africa/ebola-epidemic-west-africa-guinea.html.
Cite this as: BMJ 2014;349:g4895

(๑) BMJ Publishing Group Ltd 2014 